MATEC Web of Conferences 17, 01014 (2014)

DOI: $10.1051 /$ matecconf/ 20141701014

(C) Owned by the authors, published by EDP Sciences, 2014

\title{
Approaches to Construction Waste Management in Malaysia
}

\author{
M.A. Othuman Mydin ${ }^{1, a}$, J.C. Khor ${ }^{2}$, N. Md. Sani ${ }^{3}$ \\ ${ }^{1,2,3}$ School of Housing, Building and Planning, Universiti Sains Malaysia, 11800, Penang, Malaysia
}

\begin{abstract}
The concept of construction waste management was introduced a long time ago but the effort of waste minimization has, for the most part, merely been observed and not practiced. Additionally, an increasing allocation of landfills has indicated a growing production of waste. However, the allocation of funding or skills for the prevention of waste has been scarce as waste minimization has not been given enough attention. One such example is the undertaking of different stages of construction, which often does not account for future problems in construction waste. Hence, this study is intended to investigate common waste management practices on construction sites in Malaysia. As part of this investigation, site observations and questionnaires were conducted to collect information from the respondents. Comprehensive literature reviews also helped to understand the latest norms as well as previous practices in waste management. The results reflected that certain areas of knowledge and implementation showed great gaps with the same mistakes appearing frequently, pointing to the conclusion that known causes of excess waste are often not rectified and suggestions for improvement are not fully incorporated in standard practices.
\end{abstract}

\section{Introduction}

Construction is an industry that produces a significant amount of waste and construction sites produce waste as a result of the construction work being performed there. In the context of direct waste, a mixture of surplus materials arising from any kind of construction work is produced, be it construction, site clearance, excavation, renovation or refurbishment. Construction waste consumes a large amount of natural resources and, hence, a strategic management system is necessary to reduce or manage construction waste [1]. Some studies have showed that waste represents a relatively high percentage of production costs. Previous researchers have defined waste as the loss of any kind of resource produced by activities which generate direct or indirect costs and do not add any value to the final product from the point of view of the client [2].

Society's concern has gone from a perspective of efficiency to the impact on the environment. It is undeniable that the waste generated has caused an impact on the environment, however, building waste can hardly be recycled as it may be highly contaminated in the process of production or assembly. Building materials and inventory on site will contribute to waste generation if not handled properly and systematically [3].

Conventional projects in Malaysia seem to adopt less effective strategies in waste management. Practices to reduce, reuse or recycle waste have not yet achieved widespread implementation for a

\footnotetext{
${ }^{\mathrm{a}}$ Corresponding author : azree@usm.my
} 
number of reasons. This may due to the cost incurred in handling and transporting the physical waste to the dumpsite [4]. Employers with low initial funds may tend to allocate less to a waste management budget which leads to a reduced priority in site management. Some even believe that the cost of reusing or recycling waste is not worth the result [5]. This research is meant to reveal various losses arising from material wastage and to propose measures that will enhance the judicious use of clients' money, coupled with an overall effect on cost savings on construction projects, as well as lead to increased profits and time saving during the construction period [6]. It will also serve as a form of enlightenment to the general populace, particularly those in the construction industry [7].

\section{Methodology}

Secondary data from literature reviews was used to supplement this research; a combination of qualitative and quantitative data was collected in order to study the approaches to construction waste management in Malaysia. Qualitative data was accompanied by site observations made to two construction sites based in Pulau Pinang. Site tours and interviews carried out on the construction sites were accompanied by the persons-in-charge. Observations were made regarding the current practices and situations on the sites. Quantitative data collection was carried out to provide statistical figures for the raw data collection. A total of 120 participants responded to the distribution of the close-ended questionnaire.

\section{Results and Discussion}

\subsection{Site Observations}

In general, a worksite will always be staffed with the appropriate level of manpower, be it labourers, mechanics, or operators and there is always a superintendent or foreman on hand. A wellorganized site will then yield higher productivity, hence, achieving higher performance. Information about each site was received through an interview with the person-in-charge for each respective location and observations were made while touring the physical sites. Two construction sites based in Pulau Pinang were chosen at random. The identities of the sites will remain anonymous to protect the confidentiality of the sites.

\subsubsection{Site A}

Located at Jelutong, George Town, Site A was a construction project for mixed development to build 3-storey shop houses and two blocks of multi-storey buildings for medium-cost housing on a podium car park (Figure 1). The building has been under construction for half a year and is expected to achieve a gold rating on the Green Building Index (GBI).

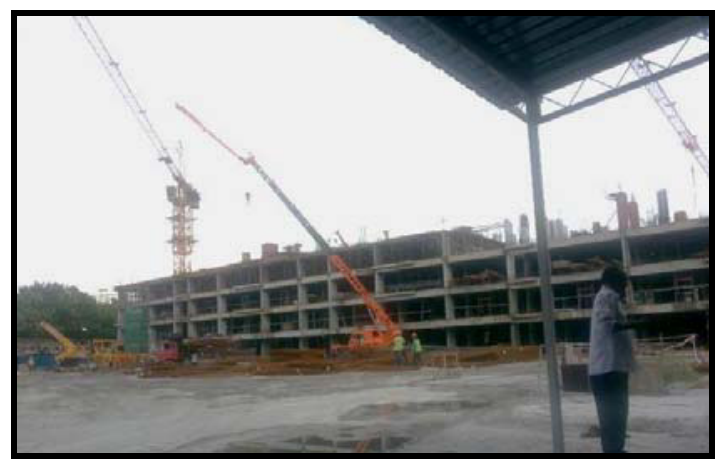

Figure 1: Façade of the multi-storey, residential building at Site A, located at Jelutong, Penang 
The overall condition of the site was observed through an interview with the Senior Project Manager, Mr. Ooi Hock San, and a site walk-through led by QAQC Officer, Mr. Mohd Faidhi Faqih Bin Qukri. There were three disposal bins prepared at the site for the collection of discarded materials. Any unwanted materials were collected and discarded into the skid bin. At the time, the most discarded materials were timber because the building was in the building stage which required large amounts of timber to be used as the formwork. The concrete casting workers and formwork cutting workers handled the timber from the production of the formwork till the installation to the structure. Then, leftover, used timber would be modified and reused for similar procedures.

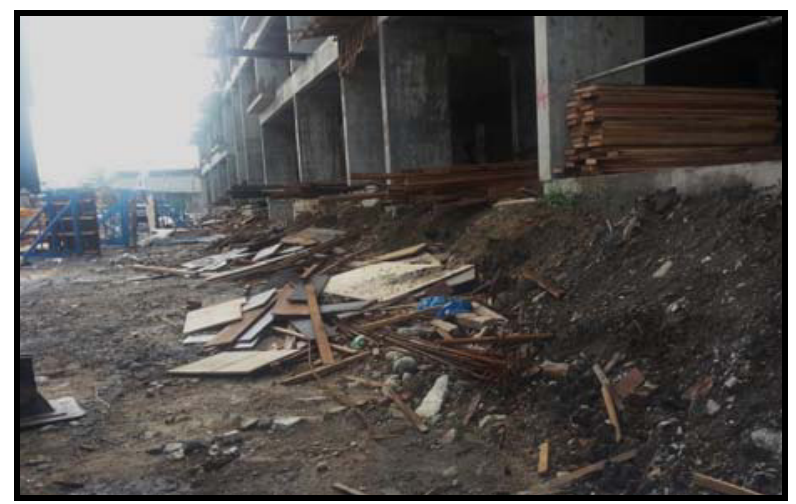

Figure 2: Unwanted materials scattered on the ground near the building.

The project team hands over the responsibility of managing the waste once the bins are full. A waste management contractor is then called to remove the waste from the site. From past experience, waste such as timber, aggregates and steel bars will be recycled or sold to outside parties. At this site, storage of materials did not receive appropriate attention from the project team. Unwanted materials were scattered on the ground as shown in Figure 2. Scenes including timber panels left on wet surfaces without any care were often seen on the site with remains of timber pieces, steel bars and aggregates scattered around the site's surroundings. Other than handling the responsibility of minimizing waste for third parties, the project team reused concrete debris left over from demolition as a road base on the construction site.

\subsubsection{Site B}

Site B was a mixed development project involving the erection of a multi-storey condominium block (Figure 3) and shop houses (Figure 4) located in Bayan Lepas.

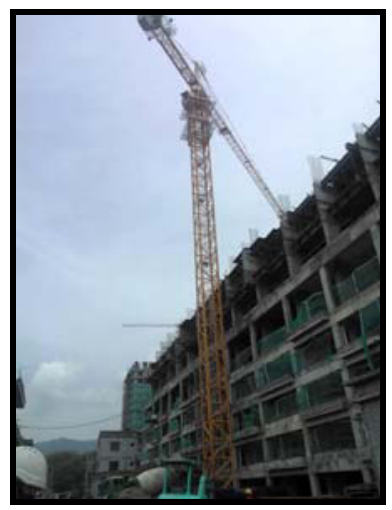

Figure 3: Construction at Site B

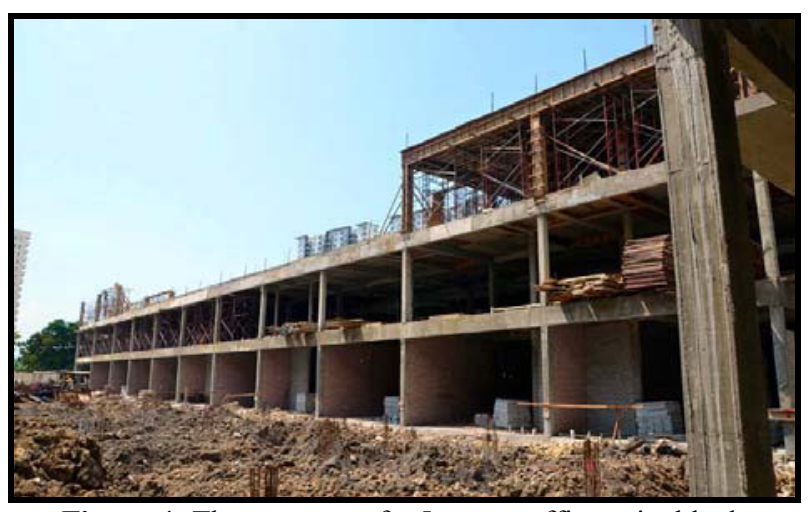

Figure 4: The progress of a 5-storey office suite block 
At Site B, materials were stored neatly according to their frequency of usage in the building stage. A rough wash was prepared to clean vehicles exiting from the site and housekeeping appeared to be a minor problem on the site. One common material waste that appeared on the site was steel bars, as the on-site fabrication of steel bars for the structural works, requiring production for different specifications, produced a significant amount of waste. The steel bars came in uniform lengths and experienced workers then cut and bent them according to the specifications. Timber was frequently found on the construction site because of its low cost and easy management. This is because easy cutting and fabrication of timber allows it to be shaped more easily than steel formwork.

Similar to Site A, Site B prepared three skid bins at different corners of the site for the collection of material waste. Waste sub-contractors were responsible for the transporting and disposal of the waste. Waste material would be collected at each work site before being transferred to the skid bins for a more convenient and efficient work flow. For example, paper bags containing cement, which would then become packaging waste, were collected near the place for mixing mortar as demonstrated in Figure 5.

Common materials found were scaffolding, steel bars, timber pieces and bricks (Figure 6). It was observed that such materials were kept in order and tidy, but no proper storage location was provided. Regarding timber formwork, alterations were made so that they redesigned for another use. Although materials were placed close to the building without blocking the road, the situation appeared to be messy, especially on rainy days. However, 5-10\% extra materials were always ordered and stored on site to keep up with the progress of the project.

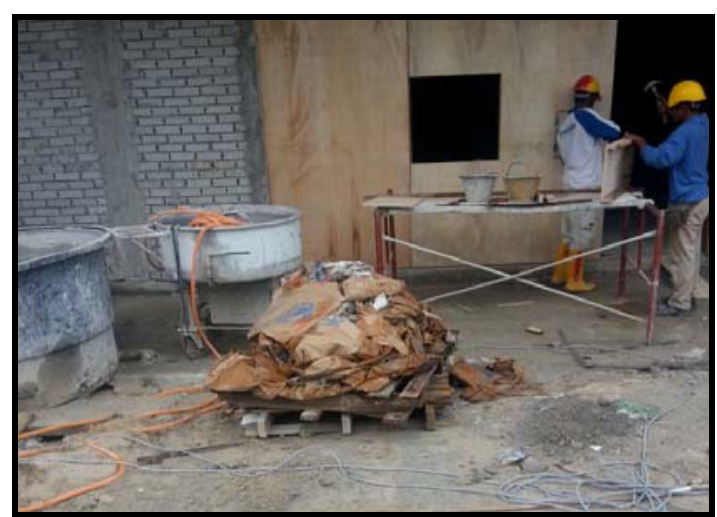

Figure 5: The collection of packaging waste

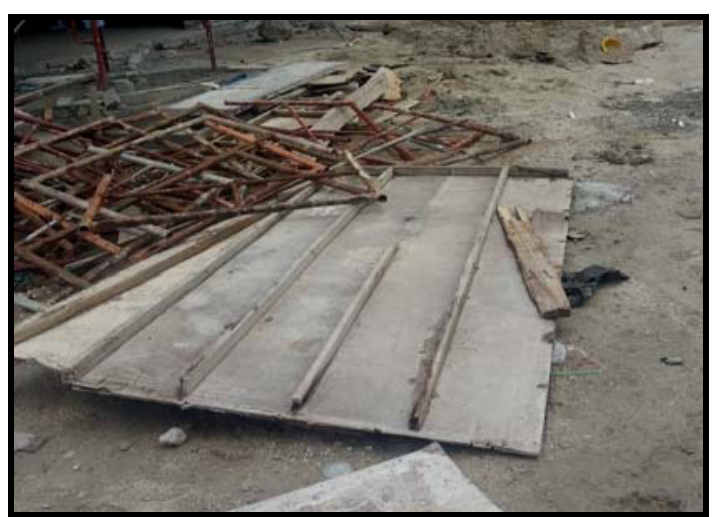

Figure 6: Timber formwork abandoned to the side

Considering the total quantity of timber involved, only $30 \%$ was reused. The remaining timber materials were exported to other sites for continued usage. Human error, redesigning of work and unavoidable damages were regarded as the most prominent causes of this waste. One example found on the site was the incorrect erection of a wall. The wrongly-built box up wall underwent alternations such as hacking by workers in order to comply with the approved blueprints.

\subsubsection{Quantitative Data Analysis}

Out of 120 respondents who took part in the survey, 55\% were male while $45 \%$ were female. The distribution of professions had a tendency towards a certain group of professions among the respondents. Seventy respondents had obtained a bachelor's degree as their highest level of education in the field while only five were PhD holders. As high as $79 \%$ of respondents were undergraduates while only $21 \%$ had finished postgraduate studies. 


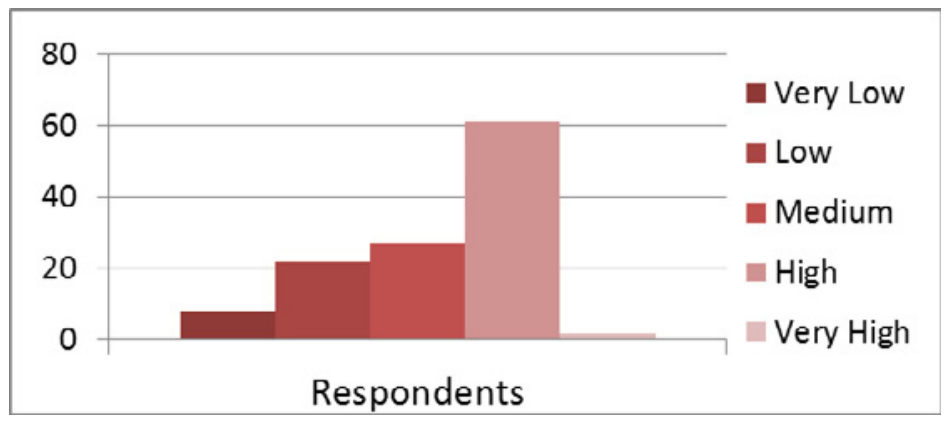

Figure 7: Perception of level of awareness regarding construction waste.

Distribution of professions was not extreme; architects, engineers, contractors and quantity surveyors formed the majority of respondents. Those from other professions who took part in the survey were developers, building surveyors, among others. Although the ages of the respondents were evenly distributed, ranging from 20 to above 40 years old, half of the respondents had been involved in the industry for over 10 years.

According to Figure 7, half of the respondents reflected that the level of construction waste in Malaysia was 'high'. Despite all the waste problems and efforts by the authorities to remedy them, those involved in construction work actually thought that the level of awareness was high. However, the persistent occurrence of problems in the industry suggests that the implementation of waste management is not up to standard. The standard deviation of 0.98 shows that the opinions of those surveyed varied and there was no majority view. As a result of the growing amount of waste, government bodies have planned to open nine more new landfills [8].

Table 1: Frequencies of materials found as construction waste

\begin{tabular}{|l|c|c|c|c|c|c|}
\hline \multicolumn{1}{|c|}{ Material } & $\begin{array}{c}\text { Very } \\
\text { Low }\end{array}$ & Low & Moderate & High & $\begin{array}{c}\text { Very } \\
\text { High }\end{array}$ & $\begin{array}{c}\text { Mean } \\
\text { score }\end{array}$ \\
\hline Timber & & & & & $\checkmark$ & 4.48 \\
\hline Steel & & & & $\checkmark$ & & 3.49 \\
\hline Brick/block & & & & & $\checkmark$ & 3.76 \\
\hline Concrete & & & & $\checkmark$ & & 3.85 \\
\hline Packaging & & & & $\checkmark$ & & 3.85 \\
\hline Sand, lime or premixed mortar & & & $\checkmark$ & & & 3.43 \\
\hline Tile & & & $\checkmark$ & & & 3.11 \\
\hline Wire and pipe & & & $\checkmark$ & & & 2.78 \\
\hline
\end{tabular}

Some data were compiled from the results that take a closer look at the materials involved in construction waste management. As can be seen from Table 1, the material which obtained the highest mean score was timber with a score of 4.48. Timber is regarded as a non-renewable source of energy which is in danger of depletion [30]. However, timber is widely used in construction projects, especially in the fabrication of building frameworks. As previously explained, timber is widely used in framework because of its light weight and low cost. Because timer is easy to cut and handle, shaping the framework is made simple.

According to the results, steel obtained a relatively high mean score value of 3.49 . The presence of steel waste is mainly due to unusable pieces resulting from trimming down steel bars which only come in one length. Additionally, errors in cutting increase thanks to poor in standardization and detailing of structural elements [9]. Considering the difficulty of controlling the amount of premixed concrete deliveries, concrete, as a waste material, obtained a mean value of 3.85 . 


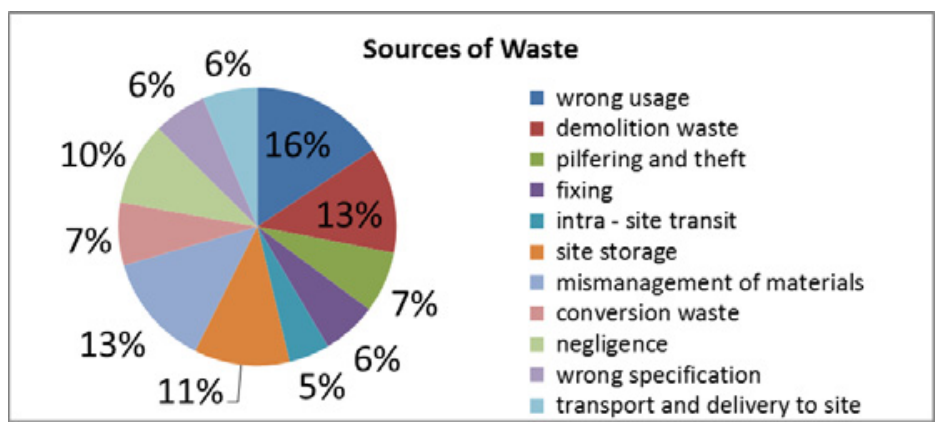

Figure 8: Sources of waste

Surprisingly, tile only obtained a mean score of 3.11. Due to the high cost of tiles, wastage was cautiously observed and prevented. The majority of tile wastage resulted from cutting them, and it was found that the cutting of floor tiles was done more frequently than the cutting of wall tiles [9]. The reason tiles needed to be cut was due to the poor coordination and integration of architectural and structural design. However, tile was not the default material in the construction project. Hence, preventing the usage of tile in the first place could avoid this type of undesired wastage of materials.

With reference to Figure 8, there were eight common sources of waste that were identified by respondents. The distribution of each type was even as correlated to each other. Several human factors were identified such as mismanagement of materials, negligence and wrong usage [10]. As site layout became a major issue in causing waste, transportation related factors were included in the survey. As seen in the case study, site storage was a major issue with many materials not housed appropriately on the site [11,12]. Having started by examining the sources of waste, the interest of this research then turned its focus to the parties responsible for materials damaged in transit. Despite all protective measures being taken, a portion of the materials appeared unusable before even reaching the site [13]. Those responsible often did not resolve the situation, hence, the project team would have to bear the resulting deficiencies.

\section{Conclusion}

This study reviewed the main issues pertaining to waste management on construction sites from the perspectives of different parties. Qualitative and quantitative analysis were carried out on different forms of data aiming to obtain a general understanding of waste management approaches in Malaysia. A thorough review of literature based on the questionnaire's core subject area helped clarify the cause-effect relationships between the investigated parameters. As a conclusion, waste management was only practiced to a certain extent. The awareness and implementation of waste minimization was of concern in only certain areas. Financial motivation can highly influence the behaviour of those involved in the construction industry, regardless of cost saving or financial incentives. Awareness should be raised in a more practical way or woven into a few crucial parameters so that the minimization of waste can be implemented in the early stages of construction.

\section{Acknowledgement}

The authors would like to thank the funding bodies of this research: Universiti Sains Malaysia under USM Short Term Grant. No. 304/PPBGN/6312147 


\section{References}

1. L. L. Ekanayake, and G. Ofori, "Construction material waste source evaluation," Proceedings: Strategies for a Sustainable Built Environment, Pretoria, 2000.

2. B.G. Hwang, and Z. B. Yeo, "Perception on benefits of construction waste management in the Singapore construction industry," Journal of Engineering, Construction and Architectural Management, Vol. 18 (4), pp. 394-406, 2011.

3. M.A. Othuman Mydin, N. Md Sani, M. Taib, N. Mohd Alias, "Imperative Causes of Delays in Construction Projects from Developers' Outlook," MATEC Web Of Conferences, Volume 10, 06005

4. S. Nagapan, A. R. Ismail, and A. Ade, "A review of construction waste cause factors," Proceedings of the Asian Conference of Real Estate: Sustainable Growth Managing Challenges (ACRE), Johor, Malaysia, 2011.

5. A. H. A. Faridah, A. H. Hasmanie, and M. I. Hasnain, "A study on construction and demolition waste from buildings in Seberang Perai," Proceeding of 3rd National Conference in Civil Engineering, Copthorne Orchid, Tanjung Bungah, Malaysia, 2004.

6. M.A. Othuman Mydin, N. Md Sani, A.F. Phius, "Investigation of Industrialised Building System Performance in Comparison to Conventional Construction Method," MATEC Web Of Conferences, Volume 10, 04001

7. H. Yunpeng, "Minimization management of construction waste," IEEE International Symposium of Water Resource and Environmental Protection (ISWREP), China, pp.2769-2772, 2011.

8. S. Nagapan, A. R. Ismail, and A. Ade, "Construction waste and related issues in Malaysia," Diges FKAAS, Vol.1, pp. 15-20, 2012.

9. C. Llatas, "A model for quantifying construction waste in projects according to the European waste list", Journal of waste management, Vol. 3, pp. 1261-1276, 2011.

10. M.A. Othuman Mydin, N. Md Sani, M. Taib, " Industrialised Building System in Malaysia: A Review," MATEC Web Of Conferences, Volume 10, 01002

11. A. Katz, and H. Baum, "A novel methodology to estimate the evolution of construction waste in construction sites," Journal of Waste Management, Vol. 31, pp. 353-358, 2011.

12. S.W. Tan, M.A. Othuman Mydin, N. Md Sani, M.Z. Sulieman, "Investigation into Common Decay of Educational Buildings in Malaysia," MATEC Web Of Conferences, Volume 10, 05001

13. R. Ndihokubwayo, and T. Haupt, "Variation orders on construction projects: Value adding or waste,” International Journal of Construction Project Management, vol. 1(2), pp. 1- 17, 2009. 